\title{
The concept of brand building process towards vietnamese enterprises in the new era
}

\author{
Vuong Khanh Tuana; Sellappan Palaniappan ${ }^{b}$ \\ ${ }^{a}$ Malaysia University of Science and Technology, ${ }^{b}$ The University of Pittsburgh
}

\begin{abstract}
THE AIMS OF THE PAPER
As customers' needs are changing very rapidly, it is important for all growing enterprises not only to provide high-quality products/services but also to exceed the customers' own expectations. Businesses need to change their marketing strategies to meet their customers' expectations, including brand management strategy which plays a vital role in conveying the value of products/services to potential customers. To increase the competitive advantage of Vietnamese enterprises in integrating with the international economy, there is a need for innovation in brand management. It is necessary to provide the concept of the brand-building process to the businesses as overview; it is vital to apply it in the planning and implementation of brand management strategy in Vietnamese enterprises.
\end{abstract}

\section{METHODOLOGY}

This empirical study has been analyzed and is presented for the future use in the concept of brand building process towards Vietnamese Enterprises. This paper was conducted in two phases. In the first phase, the researcher uses a qualitative approach to interview experts, administrators, who conduct the research on the marketing field to discuss how the phases and procedures to build a brand for the new era for Vietnamese enterprises. There were 12 experts selected to discuss to gain the model for the concepts in brand building for this new era. There were (6) questions discussed with the experts to collect the research data relative to the brand building process. Preceding this, the researcher gathered the opinions of these marketing experts to gain an overview of the process to create branding building.

\section{MOST IMPORTANT RESULTS}

The researcher summarizes four critical phases in the brand-building process for Vietnamese businesses in the new era. There are four necessary phases in building a brand as follows: (1) brand identity, (2) brand awareness, (3) brand love, and (4) brand loyalty. Depending on the strategy of the business that can be applied in the brand-building process in each individual phase or the brand- building process can combine four phases concurrently in building a branding strategy.

\section{RECOMMENDATIONS}

From the outcomes of this study, the researcher recommends that practitioners, as well as scholars can apply and research based on this study to improve in branding for businesses for sustainable development purposes in the new era.

Keywords: Brand building process, Brand identity, Brand awareness, Brand love, Brand loyalty, Vietnam

DOI: 10.15170/MM.2020.54.04.03 


\section{INTRODUCTION}

In today's highly competitive markets, retaining customers and their continued loyalty is considered critical to maintaining business performance and marketing effectiveness (Novixoxo et al. 2018). It is difficult to know whether consumers' buying decisions will accept product purchases or not because the market today is more dynamic, many products being supplied, and product life cycles getting shorter and shorter. (Poranki 2015). With the fierce competition in the market today, customers have the opportunity to consider many brands across the globe (Vazifehdoost \& Negahdari 2018). According to Thangamani (2019) "No industry has escaped the impact of globalization". Therefore, in today's fiercely competitive industry, the brand building process for products and services it is one of the essential activities for businesses to help them increase their competitive advantage and customer satisfaction.

There are promising indicators that greater credence is been given to the topic of customer-brand engagement by the practitioner as well as academic communities (Dessart et al. 2016, Islam et al. 2017, Rather and Sharma 2017a, 2017b, Rather et al. 2018), vital knowledge gaps are still evident. Additionally, many Vietnamese businesses are still quite limited in their abilities to brand build. This is evident in the sensitive period when businesses are in difficult situations due to multi-sector international investment where customers are demanding more of the products or services.

In the context of an integrated economy, businesses often face the risk of intense competition, especially when Vietnam's market has been penetrated by too many foreign goods. One of the activities that go hand in hand with businesses is building a brand strategy. Brands with added values are one of the most important avenues of gaining a competitive advantage for business in a competitive market (Veljković, \& Kaličanin 2016). The brand has then become a valuable asset in the success of a company when considering effective brand management (Sallam \& Wahid 2015). In case of Vietnam, the Vietnamese enterprises need to consider building their banding to improve the products/services in the current market. Therefore, this research paper will offer a brand building process to help Vietnamese businesses to have a new perspective on a brand building strategy to compete with foreign companies.

\section{LITERATURE REVIEW}

\section{The Concept of Brand}

There has been historic interest in branding of business products and services from marketers and academics since the 1950s (Aziz et al. 2017). The brand has become one of the most crucial platforms of the business strategy (Novixoxo et al. 2018). Curiously, one of the hottest points of disagreement among experts, is the definition of the brand (Kapferer 2008). The brand is understood in different contexts but considered from differing opinions and perspectives. The brand represents the soul of the business and helps it succeed.

Branding is the foundation, the core of the business to help companies to succeed in the market. "Brands are considered an asset that generates revenue and increased value for a company" (Narayan 2012). Brands are intangible assets, posted eventually in the balance sheet as one of several types of intangible assets (a category that also includes patents, databases and the like); brands are conditional assets; this is a crucial point commonly overlooked. An asset is an element that can produce benefits over a long period (Kapferer 2008). Therefore, the brand is the property of an enterprise; it is a combination of many factors, the achievements that the business has built during its operation. It is the reputation of the brand as a guarantee for the potential profit of the business and helps businesses to affirm their position in the market.

\section{The Important Role of Brand Building for Enterprises}

According to Novixoxo et al. (2018), in today's highly competitive markets, securing and retaining its customer's loyalty is considered a significant contributor to enhancing the business and promoting its marketing performance. One of the essential components of management over the years is the brand, whose value is reflected in the intangible assets of the enterprises (Vazifehdoost \& Negahdari 2018). For customers to buy a product or service of a specific business, the credibility, beliefs, and inspiration to buy cannot help appearing in the hearts of customers. There is a need for the motivation of customers to purchase and be loyal to that business.

According to Tabish et al. (2017), brand loyalty is essential and a vital issue to maintain the business. Focusing on brand loyalty is becoming a necessary factor in achieving long-term profitability and competitive advantages. A known brand 
makes an easy selection for customers, reduces risks and provides the suitable level of quality that they require (Vazifehdoost \& Negahdari 2018). A brand is formed with intellectual property rights, bringing legal rights to the owner. Additionally, "Consumer-brand relationship in the last decade has gained much attention from both practitioners and academics" (Ahmed and Gabriella, 2012). These intellectual property rights ensure that businesses can safely invest in brands and gain profits from valuable assets. Branding provides the customers with trust, safety, comfort, hope and a higher esteem, etc., about these products and services.

\section{The Process of Brand Building}

Brand building can be understood as the developmental phases within brand management for the products or services for enhancing business performance. Alternatively, it can be understood as a separate step or the integration of the branding phases to make a difference to its competitors and enhance its attractiveness to potential customers. The branding process is a cultural-oriented phenomenon and long-term commitment and very similar to lifestyle changes, which takes time to nurture and develop (Karmokar 2014). The process of brand building plays a vital role instilling greater; belief, inspiration, related emotions, etc., towards its customers. Enterprises should develop the brand building process that identifies the value-adding differences compared to its competitors, to stand out from the others and create additional success. The below discussion are the steps of the process of brand building:

\section{Brand Identity}

The theory of customer-brand identification creates a concise understanding regarding the development of customer-brand relationship (Bhattacharya \& Sen 2003, He et al. 2012, So et al. 2017, Tuskej \& Podnar 2018, Rather et al. 2018). Brand identity is the first and essential step to convey the message of products and services to the potential customers.

There are many different views in different contexts about brand identity. Brand identity is defined as the extent to which consumers see their images or overlap brand images (Sallam \& Wahid 2015). Besides, they mentioned that the concept of brand identity is built on the theory of social identification, which has been widely used in other industries. Brand identity is everything visual about a brand, including color, design, and brand logo, etc. It is similar to the way an enterprise or business presents itself to the public (Kimbarovsky 2019). Therefore, brand identity can also be said to be defined as a sign of differentiation between products and services on the market when products are launched, or the brand's communication of the business is widely identified to customers.

Brand identity needs to focus on the differences that bring sustainable competitive advantage for the corporations (Karmokar 2014). Stronger brand consumers often engage in brand advocacy activities, such as supporting corporate goals, protecting reputation, supporting products, and brand loyalty (Sallam \& Wahid 2015). Therefore, to build a brand identity is the first step for the products or services in the current market. Therefore, brand identity is essential for customers to recognize the good services or products providers.

\section{Brand Awareness}

Padhy \& Sawlikar (2018) and Poturak \& Softić (2019) states the consumer knows the brand awareness and image i.e., how the consumer associates the brand with themselves. Most brand awareness is expressed in terms of brand identity or brand recall (Yatundu et al. 2016). Brand awareness means the ability of consumers to recognize and recall a brand in different situations (Vazifehdoost \& Negahdari 2018). Brand awareness includes brand recall. Brand recall means that when consumers recognize a product portfolio, they can remember the particular brand name and brand identity. This means that consumers can identify the products or services by the corporate identity in the market. That is, consumers can recall a brand precisely if they have ever seen or heard it (Vazifehdoost \& Negahdari 2018). Therefore, brand awareness is an essential stage for customers to feel about products or services before they prefer a brand.

The concept of brand awareness is understood as the degree to which a brand is recognized by potential customers and correctly linked to a specific product (Poranki 2015). The researcher also pointed out that brand awareness is related to the brand identity function in the minds of consumers and can be reflected by how consumers can identify brands in various market conditions (Keller 1993). Customers cannot buy the product if they do not know about it. An important goal must be to create product awareness (Yatundu et al. 2016). Therefore, brand awareness has a positive impact on a company's success. 
Many studies also suggest that the higher awareness in the brand, the higher the perceived quality (Vazifehdoost \& Negahdari 2018). If the brand is maintained in mind of the customers, they will continue to select your branded product or service with the assurity they are receiving a valued product or service. Brand awareness must build both emotional and physical values. When customers feel good about the brand, it will be easier to transition to the following stages such as; brand preference and brand loyalty.

\section{Brand Love}

Brand managers are developing new avenues to improve their brands loved by customers (Rauschnabel et al. 2015, Sallam 2014, Wallace et al. 2014, Palusuk et al. 2019). According to Palusuk et al. (2019), "Brand love has received increasing attention given its potential to enhance customer engagement, brand advocacy, commitment and loyalty". When customers use a brand or through the opinions of friends and relatives. Brand love is a vibrant concept that has recently emerged in the field of consumer behavior that translates into increased loyalty, intention to pay a high price, and positive word of mouth (Sta et al. 2018). Therefore, the brand love is a critical factor that the enterprises need to study and develop a suitable strategy.

The goal of marketing is to convey the value of products and services to the target customers and make them love the brand. Customers can view a brand as an individual, so they can enjoy a brand like they love a person (Sallam \& Wahid 2015). When customers love the particular brand, they will continue to rebuy and remain loyal.

In recent years, there are many views about brand love. So how is brand love understood? Carroll \& Ahuvia (2006) define love for a brand as "the degree of passionate, emotional attachment that a person has for a particular trade name." Carroll \& Ahuvia (2006) noted when considering brand love is a combination of emotions and passion of an individual relative to a brand; besides, they defined love for a brand as the levels of passion and its emotional relationship that a person has for a particular brand name.

According to Sallam \& Wahid (2015), brand love is an original marketing structure, which has been shown to influence essential marketing variables such as word of mouth and purchasing decisions. When customers focus on the positive aspects of the enterprises, and they love their brand, they often form loyalty to the enterprises, and this leads them to build links — a positive brand equity for the company's products and services (Sallam \& Wahid 2015). Marketers should develop an appropriate strategy for brands to have a strong emotional appeal and target customers to love the brand (Sta et al. 2018). Customers who love the brand, they will have a positive attitude and share that feeling for friends and relatives. Therefore, based on the above statements and analysis, brand love is an essential step in the brand-building process of an overall branding strategy to improve customer loyalty.

\section{Brand Loyalty}

Loyalty is based on how much consumers consume the brand's goods or services, which we measure by measuring the frequency of consumer purchases (Novixoxo et al. 2018). When customers use certain products and services, they are satisfied and love a brand and they tend to be loyal to the brand. Loyalty is an essential step in the branding strategy of academics and practitioners. Brand loyalty is a concept that has gained considerable interest in recent years from both marketing practitioners and scholars (Worthington et al. 2009). Brand loyalty is a type of brand commitment that creates buy-back behavior for customers despite the potential marketing efforts of competitors to break the alliance between brands and consumers (Oliver 1999).

Brand loyalty is a significant concern for marketing researchers and practitioners. Brand loyalty is an essential issue for many marketing managers; The enterprises spend millions of dollars every year to track brand loyalty through marketing research organizations (Mohammed et al. 2017). Brand loyalty is the repeated purchase of any customer that reflects their conscious decision to repeat buy and show a positive attitude towards the brand to buy that product in the future (Tabish et al., 2017). Brand loyalty is the attitude of consumers to the brand's preferences (Vazifehdoost \& Negahdari 2018). In the case of intense competition, brand-specific loyalty is significant to the success of organizations (Alkhawaldeh et al. 2017). Due to the values gained from brand loyalty, many enterprises will devise different strategies to maintain and improve the customer loyalty (Novixoxo et al. 2018). The higher the level of commitment, the lower the marketing costs because loyal customers trust the brand effectively.

In the view of strategic brand management, scholars suggest that brand experience plays a vital role in influencing on brand loyalty (Hussein 2018). Brand loyalty exists when customers feel that the 
brand has the good product characteristics, the right quality and a reasonable price. "Brand loyal consumers do not evaluate the brand; they just make a purchase confidently" (Vazifehdoost \& Negahdari 2018). Even if other brands sell the product at a lower price or higher quality, customers still choose the brand they are loyal and trusting. Poturak and Softić (2019) states "Brand loyalty is a major component of brand equity". Customer loyalty to the brand is the customers constant buying habit. If a brand can meet its customers will feel loyal to the brand.

\section{METHODOLOGY}

This paper is conducted in two phases. In the first phase, the researcher uses a qualitative approach to interview experts, administrators, who work and do research on the marketing field to discuss how many phases and the procedures to build a brand for the new era for Vietnamese enterprises. The researcher gathered the opinions of these marketing experts to get an overview of making an overview process of branding building. The researcher has selected 12 experts to discuss to get the model for the concepts in brand building for this new era. There were (6) questions discussed with the experts to collect the research data relative to the brand building process. The information of the interview will be collected and providing the synthesis data in the Table 1.

Table 1. Detailed overview on the empirical data

\begin{tabular}{|l|l|l|}
\hline Informants & Job title & Duration of interview \\
\hline Expert 1 & CEO & $25: 20$ minutes \\
\hline Expert 2 & Business Consultant & 45 minutes \\
\hline Expert 3 & Business Consultant & $12: 05$ minutes \\
\hline Expert 4 & Marketing specialist & $15: 08$ minutes \\
\hline Expert 5 & Sales Manager & $23: 10$ minutes \\
\hline Expert 6 & Marketing manager & $21: 26$ minutes \\
\hline Expert 7 & Business Development & $43: 25$ minutes \\
\hline Expert 8 & Marketing manager & $13: 15$ minutes \\
\hline Expert 9 & Brand Manager & 35 minutes \\
\hline Expert 10 & Marketing manager & 45 minutes \\
\hline Expert 11 & CEO & 22 minutes \\
\hline Expert 12 & Business Development & 15 minutes \\
\hline
\end{tabular}

\section{Source: Own construction}

When conducting the interviews, the researcher has utilized simplistic terminology within the questions to ensure a complete understanding of recognized issues that are contained in the questions. A similar set of questions was given to each expert, still providing freedom for the interviewee to focus on the aspects they saw most important on each question.

The characteristics of interview of these experts are as the following (Table 2 - Table 7): 
Table 2. The need to study the brand building process

Do you think that there is a need to study the brand building process to support Vietnamese SMEs in the improvement toward attaining a greater competitive advantage over their rivals in this new era?

Yes

No- Why? Discuss in details

Table 3. The need to support the brand identity when launching products/services in the market

When initiating the launch into the market, is there a need to create the strategy for brand identity to support your target market customers so they can recognize the products or services you have in the market? Yes

No - Why? Discuss in details

Table 4. The importance of brand awareness to support the consumer's perception the overall products/ services

Do you think that the brand awareness is critical to support the consumer's perception of the overall products/ services?

Agree?

Not agree - Why? Discuss in details

Table 5. The importance of brand love towards consumers when they have already used the products/ services

Do you think that the brand love is an important next step to support the consumers when they have already used the products/ services?

Agree?

Not agree - Why? Discuss in details

Table 6. The brand loyalty is the destination for marketers to pursue the consumers who will introduce or buy products/service again in their life

Do you believe that the brand loyalty is the destination for markers to pursue the consumers who will introduce or buy products/service as repeat buyers?

Agree?

Not agree-Why? Discuss in details

Table 7. The brand building process

Do you think that the brand building process as Brand identity- Brand awareness- Brand love- Brand loyalty are the process that are suitable for enterprises to improve their brand in the market?

Agree?

Not agree - Why? Discuss in details 
In the second phase, the researcher reviews the theory of brand management and related studies to summarize the importance of branding and the brand-building process. Preceding this, the researcher will rely on relevant studies and marketing experts' opinions to propose the concept of the branding process for Vietnamese enterprises in the new era.

\section{FINDINGS}

There is a need to study the brand building process to support Vietnamese SMEs in the improvement toward attaining a greater competitive advantage over their rivals in this new era. As an overview the combined number of experts disagreeing with the issues raised is very low and shows that expert opinions agree with the need for brand building to ensure sustained success in the new era. The 12 selected experts to discuss the branding building issues towards Vietnamese enterprises in the Table 8 has results of 11 experts in favor of brand building and only 1 disagreeing. The overwhelming number of experts agree that there is a need for the SMEs to adopt brand building as a critical phase in the success of their businesses.

There are 9 out of 12 experts agree that, when contemplating a divergence into a market, is there a need to create the strategy for brand identity to support your target market customers so they can recognize the products or services you have in the market.

There are 11 experts that have agreed that they must consider brand awareness as it is critical in supporting the consumer's perception of the overall products/services. They also commented that, relating to the brand awareness phase, enterprises need to portray its good service to service aspects to its customers. This will support the customers perceive the quality of services are good and leads to customer satisfaction and becoming loyalty.

It is noted that 7 experts have agreed, brand love provides the important next step in supporting its consumers after they have already used the products/ services. They also analyzed that the enterprises need to commit to provide the good products/ services to the customers. They need to communicate the differentiation points of their products/services in the market and improve overall branding strategy for their enterprises.

It is also noted that 11 experts have agreed, brand loyalty is the goal for markers in the pursuit of consumers who will introduce or buy products/ service as repeat buyers. They commended that, to build the branding strategy with the target to attain the customer loyalty, not only provide the outstanding services/products, the enterprises need to communicate the intangible values of their services/products. There is a need to provide the new services/ products in the future to serve the need and want for the customers and the post services also provide with the outstanding quality.

From the outcomes of the study, it is evidenced that, 10 out of 12 people agree with the branding building process towards Vietnamese enterprises in the following steps as (1) brand identity; (2) brand awareness; (3) brand love; (4) brand loyalty. This process when applied will give greater success for the marketers in the overall success and sustainability of their company's banding in the new era. The opinions of the experts will be presented in more detail below in the following conclusions and recommendations 
Table 8. The percentages of expert's response

\begin{tabular}{|c|c|c|c|c|}
\hline No & The contents of the discussion & $\begin{array}{l}\text { Total } \\
\text { number } \\
\text { of experts } \\
\text { interviewed }\end{array}$ & $\begin{array}{l}\text { Number } \\
\text { of experts } \\
\text { that agree }\end{array}$ & $\begin{array}{l}\text { Num- } \\
\text { ber of } \\
\text { experts } \\
\text { that } \\
\text { disagree }\end{array}$ \\
\hline 01 & $\begin{array}{l}\text { There is a need to study the brand building process to } \\
\text { support Vietnamese SMEs in the improvement toward } \\
\text { attaining a greater competitive advantage over their } \\
\text { rivals in this new era. }\end{array}$ & 12 & 11 & 1 \\
\hline 02 & $\begin{array}{l}\text { When initiating the launch into the market, is there a } \\
\text { need to create the strategy for brand identity to support } \\
\text { your target market customers so they can recognize the } \\
\text { products or services you have in the market. }\end{array}$ & 12 & 9 & 3 \\
\hline 03 & $\begin{array}{l}\text { The brand awareness is critical to support the consu- } \\
\text { mer's perception of the overall products/ services. }\end{array}$ & 12 & 11 & 1 \\
\hline 04 & $\begin{array}{l}\text { The brand love is an important next step to support the } \\
\text { consumers when they have already used the products/ } \\
\text { services. }\end{array}$ & 12 & 7 & 5 \\
\hline 05 & $\begin{array}{l}\text { The brand loyalty is the destination for markers to pur- } \\
\text { sue the consumers who will introduce or buy products/ } \\
\text { service as repeat buyers. }\end{array}$ & 12 & 11 & 1 \\
\hline 06 & $\begin{array}{l}\text { The brand building process as Brand identity - Brand } \\
\text { awareness - Brand love- Brand loyalty are the process } \\
\text { that are suitable for enterprises to improve their brand } \\
\text { in the market. }\end{array}$ & 12 & 10 & 2 \\
\hline
\end{tabular}

Source: Own construction

\section{CONCLUSIONS AND RECOM- MENDATIONS}

Based on previous studies and marketing theory and with a combination of qualitative research utilizing expert interviews in Vietnam to develop and propose the process of brand building. As a result, the researcher summarizes four critical stages in the brand-building process for Vietnamese businesses in the new era. The method for branding is proposed by the researcher are as follows (Figure 1):
Figure 1. Brand building process

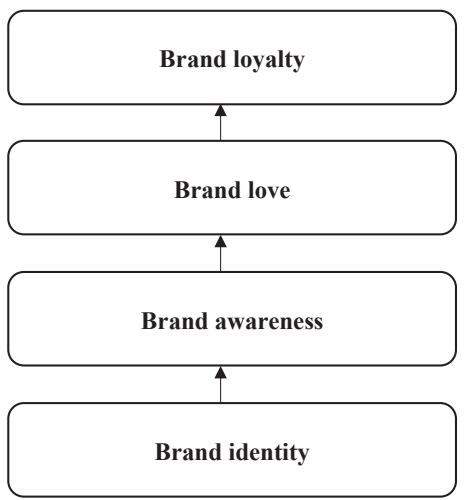

Source: Own construction 
Based on the above process, there are four necessary phases in building a brand as follows: (1) brand identity, (2) brand awareness, (3) brand love, and (4) brand loyalty. Depending on the strategy of the business that can be applied in the brand-building process in each individual phase or the brandbuilding process can combine four phases concurrently in building a branding strategy.

Brand or branding is no longer merely a sign to identify and distinguish the products and services of a particular business with their rivalries. The value of a brand is much higher; it is a valuable asset as the reputation of the enterprises and demonstrates consumer confidence in its products. Branding plays a vital role in businesses; it assesses the success and position of the product or service in the marketplace. Many strategies focus on excellent product quality but they need to incorporate additional focuses such as; branding for their businesses to increase competitive advantage and to make customers loyal to their enterprises.

Brand management should analyze their products or services before applying the brand-building process to their brand strategy as the following basic issues:

- The value of the brand's greatest benefit to its customers, manifests, promises and experience-specific actions.

- Deeper understanding the market: potential business environment, market size, competitors, etc.

- Who is the potential customer? What is a hobby or interest? What key factors will affect the target customers?

- Benefits to customers when using products and services. Includes both physical and emotional benefits.

- $\quad$ Brand values and personality characteristics. What are the key deciding factors to customers when it comes to selecting brands.

- What instills trust in the brand for customers? (unique selling point, quality of service, etc)

- The single most compelling reason for the target consumer to choose the brand.

The proposed steps for brand building process in this study are: brand identity, brand awareness, brand love and brand loyalty. Depending on the strategy of each business, the enterprises can build a branding in the individual phases or build a combination of the above four phases simultaneously. Based on this research, the researcher recommends that the future researchers and practitioners can apply this process of brand building flexibly in specific phases; or combination full phases in building a brand for the business.

\section{LIMITATIONS AND FUTURE STUDIES}

During the research process, due to limited time and conditions, this research has certain limitations. It is a qualitative research framework to develop in this research and the percentage of sampling has been limited to a small volume in the overall market volume.

Based on this finding, the future study can apply (4) phases of brand building process to study in-depth to add more detailed values in brand building process. Additionally, the CSR communications and the influence on the brand building process (e.g., Brand awareness), it is the suggestion that future studies can investigate how CSR, CSR Communication influences brand building relative to Vietnam. 


\section{REFERENCES}

Ahmed, R.I., \& Gabriella, S. (2012), "Effects of brand love, personality and image on word of mouth: The case of fashion brands among young consumers", Journal of Fashion Marketing and Management, 16(4), 386 -398 DOI: 10.1108/13612021211265791

Aziz, S. A., Jusoh, M. S., \& Amlus, M. H. (2017). "Investigating Critical Success Factors of Brand Loyalty: A meta-data analysis approach", International Review of Management and Marketing,7(3), 233-237

Bhattacharya, C. B., \& Sen, S. (2003), “Consumer company identification: a framework for understanding consumers' relationships with companies", Journal of Marketing, 67(2), 76-88 DOI: 10.1509/jmkg.67.2.76.18609

Carroll, B. A. \& Ahuvia, A. (2006), Some antecedents and outcomes of brand love. Marketing Letters, 17(2), 79-89 DOI: 10.1007/s11002006-4219-2

Dessart, L., Veloutsou, C., \& Morgan-Thomas, A. (2016), "Capturing consumer engagement: Duality, dimensionality and measurement", Journal of Marketing Management, 32(5/6), 399-426 DOI: $10.1080 / 0267257 x .2015 .1130738$

He, H., Li, Y., \& Harris, L. (2012), "Social identity perspective on Brand loyalty", Journal of Business Research, 65(5), 648-657 DOI: 10.1016/j. jbusres.2011.03.007

Hussein, S.A. (2018), "Effects of brand experience on brand loyalty in Indonesian casual dining restaurant: roles of customer satisfaction and brand of origin", Tourism and Hospitality Management, 24(1), 119-132 DOI: 10.20867/ thm.24.1.4

Islam, J. U., Rahman, Z., and Hollebeek, L. D. (2017), "Consumer engagement in online Brand communities: a solicitation of congruity theory", Internet Research, 28(1), 23-45 DOI: 10.1108/intr-09-2016-0279

Kapferer, J-N. (2008), The New Strategic Brand Management, London: Kogan Page.

Karmokar, P. P. (2014), "All about Brands and Brand Building”, International Journal of Innovation and Scientific Research, 3(1), 54-61

Keller, K. (1993), "Conceptualizing, measuring, and managing customer-based brand equity", The Journal of Marketing, 1(22), 1-22 DOI: $10.1177 / 002224299305700101$

Kimbarovsky, R. (2019), What is Brand Identity and how to create a unique and memorable One. Retrieved from: https://www.crowdspring. com/blog/brand-identity/ (Accessed on September, 2019)

Mohammed, G. O., Hasaballah, A. H. A., Almohaimmeed, B. M. A., \& Al-Tit, A. A. (2017), "The impact of product performance on brand loyalty mediated by customer satisfaction: Study in Sudanese service industry". International Journal of Advanced and Applied Sciences, 4(1), 116-122

Narayan, G. (2012), "Brand valuation: A strategic tool for business", Journal of Brand Management, 9(3), 55-64

Novixoxo, J. D., Jamal-Deen, A., Anning, L., \& Darko, S. (2018), "The effect of branding on the marketing performance of companies in the mobile phone industry (case study of Techno Ghana, Accra)", International Journal of Developing and Emerging Economies, 6(2), 39-60

Oliver, R. L. (1999), "Whence customer loyalty?", Journal of Marketing, 63, 33-44

Padhy, S.K. \& Sawlikar, R.K. (2018), "The Role of Brand Equity And Brand Awareness on Consumers' Purchase Intention", International Journal of Business and Management Invention (IJBMI), 7(1), 2018, 12-16

Palusuk, N., Koles, B., \& Hasan, R. (2019), “All you need is brand love': a critical review and comprehensive conceptual framework for brand love". Journal of Marketing Management, DOI: 10.1080/0267257X.2019.1572025.

Poranki, K.R., (2015), "The Impact of Brand Awareness on Customer Satisfaction: A case Study of Godfrey Phillips India Limited, India”, Research Journal of Social Science \& Management, 5(1), 38-44

Poturak, M., \& Softić, S. (2019), "Influence of Social Media Content on Consumer Purchase Intention: Mediation Effect of Brand Equity", Eurasian Journal of Business and Economics, 12(23), 17-43

Rather, R. A., \& Sharma, J. (2017a), "Customer Brand engagement for evaluating customer relationships in hotel industry", European Journal of Tourism, Hospitality and Recreation, 8(1), 1-13 DOI: 10.1515/ejthr-2017-0001

Rather, R.A., \& Sharma, J. (2017b), "The effects of customer satisfaction and commitment on customer loyalty: Evidence from the hotel industry", Journal of Hospitality Application and Research, 12(2), 41-60

Rather, R. A., Tehseen, S., \& Parrey, S. H. (2018), "Promoting customer brand engagement and brand loyalty through customer brand identification and value congruity", Spanish Journal of Marketing - ESIC, 22(3), 319-337 
Rauschnabel, P., Ahuvia, A.C., Ivens, B. S., \& Leischnig, A. (2015). "The personality of brand lovers: An examination in fashion branding", Consumer Brand Relationships: Meaning, Measuring, Managing, 1-24 DOI:10.1057/9781137427120_6

Sallam, M. A. (2014), "The effects of brand image and brand identification on brand love and purchase decision making: The role of WOM", International Business Research, 7(10), DOI: 10.5539/ibr.v7n10p187

Sallam, M. A., \& Wahid, N. A., (2015), "The effects of satisfaction and brand identification on brand love and brand equity outcome: the role of brand loyalty", International Journal of Economics, Commerce and Management, 3(2), 1-13.

So, K. K. F., King, C., Hudson, S., \& Meng, F. (2017), "The missing link in building customer Brand identification: the role of Brand attractiveness", Tourism Management, 59, 640-651

Sta, N. S., Abbassi, R., \& Elfidha, C. (2018), "The effect of brand love on brand performance: the role of brand loyalty", Journal of Business and Management Research, 314-324

Tabish, M., Hussain, S. F., \& Afshan, S., (2017), "Factors That Affect Brand Loyalty: A Study of Mobile Phone Industry of Pakistan", KASBIT Business Journal (KBJ), 10, 151-170

Thangamani (2019), "Impact of Branding on Consumer Behaviour", International Journal of Management, 6(3), 74-79

Tuskej, U. \& Podnar, K. (2018), “Consumers' identification with corporate brands: Brand prestige, anthropomorphism and engagement in social media", Journal of Product and Brand Management, 27(1), 3-17.

Vazifehdoost, H., \& Negahdari, A. (2018), "Relationships of Brand Awareness, Brand Association and Perceived Quality with Brand Loyalty and Repurchase Intention", Case Studies Journal, 7(1), 45-51

Veljković, S., \& Kaličanin, D. (2016), “Improving Business Performance Through Brand Management Practice", Economic Annals, 111(208), $1-167$

Wallace, E., Buil, I., \& de Chernatony, L. (2014), "Consumer engagement with self-expressive brands: Brand love and WOM outcomes", Journal of Product \& Brand Management, 23(1), $33-42$

Worthington, S., Russell-Bennett, R., Hartel, C. (2009), "A tri-dimensional approach for auditing brand loyalty", Brand Management, 17(4), 243-253

Yatundu, A. F., Otiso, K. N., \& Rajab, F. N. (2016),
"Brand Awareness and Its Effect on Performance of Public Sugar Manufacturing Firms in Western Kenya", International Journal of Advances in Management and Economics, 5(1), 42-47

Vuong Khanh Tuan, PhD Student vuong.tuan@phd.must.edu.my Malaysia University of Science and Technology

Sellappan Palaniappan, $\mathrm{PhD}$, Professor sell@must.edu.my The University of Pittsburgh 